\title{
The co-originality of human rights and democracy in an international order
}

\author{
Johan Karlsson Schaffer \\ j.k.schaffer@nchr.uio.no \\ Accepted for publication by International Theory.
}

Abstract: $\quad$ This paper analyses Jürgen Habermas's claim that democracy and human rights are co-original and its implications for his international theory. A central argument in his theory, the co-originality thesis suggests that human rights and democracy are not only both fundamental and mutually supportive, but also 'equi-primordial' and internally related. Reconstructing Habermas's argument as it has developed over two decades, I argue that his account of constitutional democracy has difficulties accounting for the enmeshment of constitutional and international human rights, while his three-tiered model of global governance, in the absence of democratic legitimation, amounts to a downgrade of the currently institutionalized practice of international human rights. Instead, I suggest that shifting the focus from ideal global institutions to actual processes of domestic contestation, through which groups appropriate and apply international legal norms in order to claim their rights, provides a plausible account of the practice of international human rights consistent with the co-originality thesis.

Key words: $\quad$ Co-originality, democracy, discourse theory, Habermas, human rights, practice 


\section{The co-originality of human rights and democracy in an international order}

\section{Introduction}

Most of us find both human rights and democracy important. We are so used to hearing of them in conjunction that we often regard them as virtually synonymous, expressing a common aspiration for human autonomy, dignity, equality and freedom. On the other hand, we may also easily think of cases where human rights and democracy are in tension with one another. For instance, the individual liberties often enshrined in constitutions serve to restrict majoritarian decision-making, while internationally, numerous human rights treaties set standards for what governments, no matter how democratic their credentials, may do toward their citizens.

In his philosophical account of law and democracy, Jürgen Habermas claims to resolve this tension. Human rights and democracy, he maintains, are not only both essential and mutually supportive, but internally related and 'equi-primordial' or 'co-original', as they reciprocally presuppose each other (Habermas 1996; Habermas 1998a). In this paper, I shall address the resources in a Habermasian international theory for sustaining this so-called co-originality thesis. Habermas presented his account of co-originality within a discourse theory of democracy that made few references to the particular problems of international order, which has been a key topic in his later writings on cosmopolitanism, global governance and the constitutionalisation of international law. As I will argue, Habermas's account of constitutional democracy has difficulties accounting for the interna- 
tional enmeshment of human rights, while his model of global governance, in the absence of democratic legitimation, amounts to a downgrade of the current institutionalized practice of international human rights. Instead, I suggest that shifting focus from global institutions to domestic contestation, through which sub-state stakeholders appropriate and apply international norms, reflects not only a plausible account of the practice of international human rights consistent with the co-originality thesis, but also suggests a viable alternative to leading political conceptions in the philosophy of human rights.

My core argument is that the co-originality thesis as a theory of international human rights must be able to account for two crucial aspects of the current practice of human rights: First, international human rights law is today often intertwined with domestic constitutional law. The co-originality claim, as a normative and quasi-historical thesis about the origins of liberal democracy, has mostly been formulated under the idealizing assumption of a self-enclosed national constitutional project, but it needs to account for this de facto international dimension. Second, international human rights are not primarily implemented through top-down institutions at the inter-state level, but through struggles by which societal actors appropriate international norms in order to claim equal standing against public authority. Hence, compared to the dominant understanding, I wish to give co-originality a more internationalist interpretation, while emphasizing the domestic aspects of the politics of international human rights. Reconceiving that practice in this way makes it easier to do the co-originality claim justice as a theory of human rights and democracy in an international order.

While Habermas has influenced scholarship across the disciplines in philosophy, law and the social sciences, the existing literature lacks a thorough assessment that confronts Habermas's co-originality claim, as part of a cosmopolitan theory of international 
political order, with an account of the practice of international human rights. This article contributes to that effort, but also to international theory more generally. Human rights and democracy are arguably the most powerful contemporary justificatory discourses, and how we view their normative relation has significant implications. For instance, key political philosophers (see Baynes 2009b) deny that there is a human right to equal political participation, as the co-originality claim asserts, a controversy which translates into conflicting views on, for instance, which types of regimes should be accepted as legitimate members of international society. Likewise, insisting that rights must be articulated through democratic lawmaking sets a sharp, critical standard to contemporary practice, where states increasingly authorize international judicial institutions, especially in the human rights area, to dynamically develop the content of international law (Føllesdal et al. 2013; Bogdandy \& Venzke 2012). Hence, the controversial claim that human rights and democracy are internally related and equi-primordial holds a promise to provide guidance for some of the hardest dilemmas of contemporary international politics.

My argument proceeds as follows: I reconstruct, first, Habermas's account of the co-originality of human rights and democracy and discuss, second, how it could meet two prominent objections that charge the co-originality thesis with circularity. However, beyond this I argue that whether we understand the co-originality claim as a quasisociological account of the origins of modern constitutional democracy or as a normative argument about the internal relation between private and public autonomy, dropping the assumption of a single constitutional project in isolation reveals particular challenges for the co-originality claim. Third, I outline the problems the co-originality claim faces within Habermas's international theory of global governance without a world government. Crucially, for a theory with cosmopolitan ambitions, the co-originality thesis makes it 
difficult to justify international human rights, as distinct from the rights of citizens, because rights cannot be given particular content in the absence of universal (global) democratic procedures. Fourth, I provide an alternative interpretation on which international human rights are realised through domestic political struggles rather than through international action via multilateral institutions. I conclude by reflecting on what this rational reconstruction implies for the viability of the Habermasian approach to human rights and democracy.

\section{The co-originality of human rights and democracy}

'Which comes first', Habermas (2001a) asks, 'the individual liberties of the members of the modern market society or the rights of democratic citizens to political participation?' Giving an historical account of how the principles of rule of law and popular sovereignty united into the seemingly paradoxical concept of constitutional democracy, Habermas develops his argument that human rights and democracy are internally related and cooriginal. The alleged paradox consists in that if we wish to justify constitutional democracy consistently, it seems that we must rank the two principles, human rights and popular sovereignty.

Habermas is not alone in stressing that individual rights and democracy are equally fundamental and interrelated; his theory of political legitimacy developed through critical interchanges with John Rawls and others (for overviews, see Finlayson \& Freyenhagen 2011; Pedersen 2012; Hedrick 2010). Yet, the claim about the co-originality of private and public autonomy offers a sophisticated theory about why the two forms of autonomy are interrelated (Cohen 1999). Moreover, Habermas's co-originality thesis can also be read as a quasi-historical thesis about modern constitutional democracies, which incorpo- 
rated a certain concept of positive and legitimate law and - eventually - both human rights and popular sovereignty into 'their normative self-understanding' (Habermas 1996, p.94). However, the relation is not simply an historical contingency, but also conceptual or internal, in Habermas's terms.

For Habermas, the liberal and republican traditions both stress the value of autonomy, but liberalism traditionally prioritizes private autonomy over democracy, and people are thus free to the extent that they can realize themselves and pursue their individual aspirations (without impinging on the same right of others). Vice versa, republicanism subordinates individual rights to public autonomy, the collective self-determination of the political community, and citizens are free to the extent that they live by laws that they have given themselves. Stuck between these two options, 'political philosophy has never really been able to strike a balance between popular sovereignty and human rights' (Habermas $1998 \mathrm{~b}, \mathrm{p} .258)$. That is what the co-originality thesis promises: To reconcile at a conceptual level the one with the other; public with private autonomy (Habermas 1996, p.84).

Posing the question like a paradox, Habermas prepares the ground for his own solution: that human rights and popular sovereignty presuppose each other and are internally related (cf. Taylor 2000). Neither comes first, or both, like the proverbial hen and egg:

'as participants in rational discourses, consociates under law must be able to examine whether a contested norm meets with, or could meet with, the agreement of all those possibly affected. Consequently, the sought-for internal relation between popular sovereignty and human rights consists in the fact that the system of rights states precisely the conditions under which the forms of 
communication necessary for the genesis of legitimate law can be legally institutionalized.' (Habermas 1996, p.104)

Hence, if people are to be able to exercise their popular sovereignty by participating in making the laws that govern their society, they must also be endowed with the rights that allow them to communicate and deliberate rationally with each other.

Now, this solution seems only to justify the kinds of rights that enable people to engage in deliberation with each other - rights to participate and to speak freely, for instance - but not those other rights that we may also consider important, such as civil liberties safeguarding individual privacy from government intervention. Equal rights to participate in political procedures are implied by definition in the concept of democracy, but the others, the non-political liberties, account for much of the alleged paradox, precisely because they are not already presupposed by the democratic procedure. In that case, Habermas would only be able to justify rights instrumentally: Only those particular rights are justified that enable people to participate in democratic procedures. Furthermore, if human rights primarily serve to enable people to participate in democratic procedures, then rights should be assessed as to whether they actually do so, and they might legitimately be restricted to the degree that they do not.

Anticipating such objections, Habermas argues that the non-political rights are already implied by the legal order as such (Habermas 1998b, p.259; Habermas 1998a). As a basic social fact, citizens of modern, complex societies must regulate and coordinate their interaction through the medium of law. Law also establishes a basic scheme of minimal personal liberty. A system of rights defining the citizen's status of legal person is thus constitutive of the legal medium as such (Habermas 1996, p.119). First, law allows people to decide whether to comply for strategic or normative reasons, and thus grants indi- 
viduals the minimal liberty not to give account of their reasons for complying (Habermas 1996, p.120). In Habermas's terms, the rights presupposed by the legal medium thus guarantees private autonomy by suspending the obligation of communicative freedom to respond to one's counterpart: You are free not to explain yourself to others. Second, modern law concedes to agents a certain 'latitude to act: people are free to do whatever they wish unless the law prohibits it' (Habermas 1998b, p.256; cf. Habermas 2010).

However, the legal code alone gives only a minimal account of equal liberties, and the legality or positivity of the law does not explain why it is also legitimate. In order to explicate the legitimacy of the legal order and to give a fuller account of equal liberties, Habermas invokes the discourse principle, which sets the conditions under which action norms, whether moral or legal, are valid. The discourse principle states that '[j]ust those action norms are valid to which all possibly affected persons could agree as participants in rational discourses' (Habermas 1996, p.107). Unlike moral norms, however, legal norms are not only symbolic systems of knowledge, on Habermas's view, but they can additionally be binding at the institutional level as a 'system of action'. To specify what the discourse principle means for action norms that take a legal form, Habermas introduces the principle of democracy, which establishes a procedure of legitimate law-making. The principle of democracy states that 'only those statutes may claim legitimacy that can meet with the assent ... of all citizens in a discursive process of legislation that in turn has been legally constituted' (Habermas 1996, p.110).

Habermas emphasizes that rights are not things or natural endowments that individuals possess prior to politics, but rather relations that individuals mutually recognize and confer on each other when they agree to regulate their common life via the medium of positive law. Thus, positive law relates to individual liberty, implying that 'insofar as 
individuals undertake to regulate their common life through the legal form they must do so in a way that grants to each member an equal right to liberty' (Baynes 1995, p.210). A coercive political order creates 'legally secured spaces in which citizens can exercise their freedom without undue interference' (Cronin 2006). Thus, the legal order that protects the private autonomy of the citizens also provides the institutional conditions under which citizens can address one another collectively as a democratic community, as authors of legitimate law, and that would explain why citizens must also be warranted classic liberal civil liberties in order to be both authors and addressees of legitimate law (Habermas 1998b, p.176).

What particular rights follow from this account of co-originality? Habermas suggests that five different categories of basic rights can be deduced from the conjunction of the legal code and the discourse principle. The first category of rights concerns the maximal equal liberties of all. The legal form provides the legal status of citizens and the discourse principle supposedly explains why each person should have the greatest possible measure of equal liberties compatible with the same measure for all. The second category concerns rights that regulate membership in a determinate association of citizens. The third category suggests rights anyone can invoke who feels that her rights have been infringed. These three categories of basic rights - to equal liberties, membership and legal remedies - grant citizens the status as addressees of law, but do not per se provide a full account of classic liberal basic rights, or any particular rights at all: We are still not 'dealing with an organized state authority against which such rights would have to be directed,' but moreover, the rights specified here are 'unsaturated placeholders' for specific, particular rights, because they 'must be interpreted and given concrete shape by a political legislature in response to changing circumstances' (Habermas 1996, p.125f). Turning 
to citizens as authors of law, the fourth category of basic rights grants these now constituted legal subjects equal opportunities 'to participate in processes of opinion- and willformation in which citizens exercise their political autonomy and through which they generate legitimate law' (Habermas 1996, p.123). A fifth category, finally, grants citizens the necessary 'living conditions' for exercising their rights to private and public autonomy. This category is not absolute, Habermas suggests, but instrumental to the other categories of rights.

This is a distinctively political conception of rights in so far as the scheme of rights is not derived from a theory of practical reason or a concept of moral autonomy (Mahoney 2001). Moreover, the system of rights is not imposed on the legislator from the outside: 'legal persons can be autonomous only insofar as they can understand themselves, in the exercise of their rights, as authors of just those rights which they are supposed to obey as addressees' (Habermas 1998b, p.258).

Hence, while arguing that we can deduce these five categories of rights from the legal form and the discourse principle, Habermas leaves the actual particular rights and their content open, as they can only be specified by citizens exercising their civic autonomy under particular historical conditions (Cohen 1999). Insisting that the system of rights is unsaturated until a legislative assembly articulates it follows the procedural approach of discourse ethics. It aims to specify no particular moral norms that we ought to follow, just the rules by which we should decide what we ought to do: We should follow only those norms which we believe could be reasonably accepted by all affected, but their content would have to be decided through actual public deliberation (Gilabert 2005).

Thus, Habermas proclaims to have solved what he thinks is a paradox that has haunted modern political theory since Kant and Rousseau, who both failed, for different 
reasons, to account for both human rights and popular sovereignty. However, here we anticipate the problems this theory of rights will encounter as a theory of international human rights. By premising human rights on the legal code and actual discourses, Habermas has difficulties explaining how there can be universal human rights in the absence of a global democratic legal order.

\section{Problems with co-originality}

Before turning to the international problem of human rights, let us consider two objections against the co-originality thesis, which suggest, first, that the discourse principle presupposes a liberal principle of autonomy, and that, second, without such normative constraints, the deliberative procedure would face a regress problem, since even the construal of persons as free and equal, which sets the procedure's parameters, would be up for grabs.

Identifying the first problem, critics have argued that Habermas misunderstands his own theory: The discourse principle does presuppose a fundamental respect for persons as free and equal, as a basic liberal idea of legitimacy. As Charles Larmore (1999, p.621) argues, if 'we believe our political life should be organized by some principle such as [the discourse principle], that is only because we embrace the moral principle of equal respect for persons'. Hence, the right of every person to be bound only by political principles whose justification he or she can rationally accept sets limits to democratic self-rule, Larmore claims, because it determines what sorts of expression of the popular will that shall count as democratic. And even if constitutional rights and civil liberties may serve to enable public autonomy, they are also independently and sufficiently justified because 
they protect the freedom of persons as members of civil society with its social, cultural and spiritual life (Rawls 1996, p.420).

Responding to these blows to the heart of the co-originality claim, Habermas (Habermas 1998a) cedes as much when he suggests that rights to private autonomy 'obviously' have an intrinsic value that cannot be subsumed in their instrumental value for democratic will-formation. More assertively, Stefan Rummens (2006) suggests that while Habermasians should accept that the discourse principle contains non-trivial moral presuppositions, those presuppositions can be extracted form Habermas discourse ethics, while toning down his reliance on the medium of law to justify rights: It is not the medium of law as such that shapes individual liberties, Rummens argues, but the moral preconditions of deliberative practices. On the other hand, one might suspect that by this alternative strategy to uphold the co-originality claim, discourse ethics would betray the idea that even the preconditions of deliberative practices must be dialogically formulated.

This leads to the second, related problem. A regress results from claiming both (a) that norms can only be legitimated through actual, public deliberation among free and equal persons and (b) that the fundamental parameters of such procedures - even specifying what 'free and equal persons' means - must be legitimated through democratic deliberative procedures. That is, we need a legally constituted democratic procedure to deliberatively examine the laws (and thus confer validity to them) and to bring forth valid fundamental laws. But that procedure must itself result from a conceptually prior procedural event, constituted by valid laws which, in turn, must result from an even prior legitimate procedure, and so on (Michelman 1997, p.169).

How could Habermas, or a Habermasian, avoid this regress problem? Let me suggest three solutions (cf. Kassner 2006). First, one could argue that everything is up for 
grabs in the deliberative procedure, except for some core of participatory rights. Individuals thus must have a fundamental right to participate as free and equal in order for a deliberative procedure to be legitimate, and to be able to produce legitimate results (Rummens 2006). But there is no principled reason for excluding the values of democracy from the requirement that it should always be possible to resubmit fundamental laws to actual deliberative procedures, and hence we again face the regress. Whereas there might be practical reasons to assume the right to participate (for example, to avoid the risk of a regress, we might simply decide that everything, save for this very right, is up for grabs), doing so seems inconsistent with the co-originality thesis. A second approach would state the right to participate as an initial condition, so that even if deliberation would eventually go all the way down, it would not do so in the first phase. This solution too is inconsistent with the co-originality thesis, since it makes rights, if even only the right to participate as a free and equal person, conceptually prior to the democratic procedure.

A third solution might regard the provisions specifying freedom and equality of persons as out of reach most of the time, but not always: The rights of persons to be free and equal in deliberation should be constitutionally entrenched and shielded from constant alteration in order to secure the stability and predictability necessary for the rule of law, and for citizens to enjoy and practise those rights (cf. Rawls 1996, p.406). Civil liberties would thus not be externally imposed on public deliberation and they are open to revision, but just not all the time. However, this solution too presupposes that certain values are more fundamental than, and thus legitimately constrain, the deliberative democratic procedure itself. This is what the co-originality thesis denies. Again, solving the problem on any of these terms seemingly requires concessions to liberalism. 
Being aware of the regress problem in his account of democratic constitutionalism, Habermas argues that the circle is virtuous rather than vicious. Deliberative democracy will necessarily be 'a recursively or self-referentially structured practical idea', but that does not make it logically or procedurally impossible (Michelman 1997, p.151). Although such recursive processes may be infinite, they may sustain themselves: 'the idea of the rule of law sets in motion a spiralling self-application of law' (Habermas 1996, p.39). As such, the original constitutional moment lays down a system of rights which gains legitimation retrospectively by the constitutional project it initiates (Cronin 2006). In the long run, the constitutional project is a 'self-correcting learning process' involving the collective of citizens (Habermas 2001a). This recursive justification might gain further credibility if we understand the co-originality thesis not only as a normative claim, but also as a sociological claim about constitutional rights and democracy. Habermas thus recognizes that common identity and sympathy serve an important practical function in enabling democracy, and constitutional principles must be "situated in the historical context of a nation of citizens" (Habermas 1996, p.499).

Addressing the regress problem by emphasizing how an initial constitutional founding might be recursively justified by consecutive generations of consociates under law, also underscores that the co-originality claim presupposes not only a state in the form of a legal system, but also a particular constitutional project, which is to be recursively justified. But if so, how could human rights, and not just the public and private autonomy of citizens, be internally related to democracy? This leads us to the problem of justifying international human rights by means of the co-originality thesis. 


\subsection{Domestic constitutionalism and international rights}

In the next section, I shall explore how the co-originality claim fits into Habermas's scheme of global order reform. Before turning to that, let me point to a third problem that arises once we apply the co-originality thesis, formulated under the idealizing assumption of a single constitutional democracy isolated from the surrounding world, to real-existing constitutional projects, which today are complexly intermeshed with international legal orders. Relaxing this assumption puts the co-originality thesis to a test, whether we read the thesis as a quasi-sociological account of the origins of the democratic Rechtsstaat or as a normative claim about the internal relation between public and private autonomy.

In reality, few constitutional democratic projects are today secluded from international human rights law. Take the European human rights order as an illustration. ${ }^{1}$ All 47 state parties to the European Convention on Human Rights (1953) have included the convention into the domestic legal order, making the convention binding on all public authorities and enforceable by national judges. In effect, every citizen has the right to plead fundamental rights before national courts, and, once national remedies have been exhausted, to petition the European Court of Human Rights, which interprets and applies the Convention dynamically in keeping with society's evolution (Stone-Sweet 2012, p.63). Moreover, for citizens of the European Union, the fundamental rights developed by the European Court of Justice, with its doctrines of supremacy and direct effect, "are a more important source of non-discrimination law than are national constitutions" (StoneSweet 2012, p.65). In addition, most European states have ratified several international human rights conventions, including optional protocols establishing individual com-

\footnotetext{
${ }^{1}$ While the European region stands out in this regard, ratification and incorporation of international human rights treaties shape rights provisions in domestic constitutions globally (Elkins et al. 2013).
} 
plaints mechanisms, and, to varying degrees, incorporated them into domestic law.

Hence, within and beyond the domestic constitution, a typical citizen of Europe can appeal to a dense network of international human rights norms and bodies in order to assert her rights against state authorities.

This enmeshment of international human rights law and domestic constitutional projects is challenging for the co-originality thesis. First, the interlacing of rights poses an anomaly to the co-originality claim read as a quasi-historical rational reconstruction of the sociological origins of constitutional democracy. However idealized, such a reconstruction fails to account for the international, external factors that have co-constituted contemporary constitutional democracy, including an international institutional environment increasingly hospitable to democracy and the rule of law domestically, and, specifically, the emergence of international human rights systems. Moreover, the international human rights regime not only fills gaps where domestic constitutional rights protection underperforms; it also achieves several unique functions: rendering governments objects of legitimate international concern; binding governments to external legal limits on their authority; and clarifying that even the rights of citizens have their normative basis in an idea of universal human rights (Gardbaum 2009, p.254ff). Yet the co-originality thesis seems to provide no heuristic for explaining the international origin of human rights.

Second, for co-originality as a normative claim about the conceptual relation between private and public autonomy, the international human rights regime poses several challenges. International human rights doctrine articulates a substantive scheme of rights, and, compared to domestic constitutions, international human rights treaties are usually more difficult to amend and change, especially from the citizens' perspective. Due to this rigidity - resulting from relatively specific content and complex amendment processes - 
international judicial institutions have assumed an increasingly important role not just in interpreting the treaties, but in developing and making international human rights law. Thus, international judicial institutions are deeply involved in giving content and shape to the human rights citizens enjoy, yet are even further removed from democratic legitimation and, consequently, from the ideal of free and equal citizens being both the authors and addressees of legitimate laws. Hence, not only would international human rights lack justification and legitimation unless deliberative procedures are institutionalized globally (McCarthy 1999, p.198); so would, I submit, domestic, constitutional rights, imbued as they are with international norms.

Of course, one could just retort that the international human rights regime then obviously lacks the type of democratic legitimacy required by the co-originality claim. But if so: How to solve the problem? As a theory of both constitutional and human rights, the co-originality claim faces a dilemma: Either rights need to be articulated through a global legal order, including self-sustaining processes of democratic legitimation through which citizens can become subjects of rights in the authorial sense, or international rights regimes need to be trimmed down and the articulation of rights must be confined to the legal-political orders of states, legitimated through domestic democracy. Both solutions seem unsatisfactory: The global route appears overly demanding, as the existing world order lacks democratic legitimation procedures, while the national route would forsake the unique functions performed by international human rights law for which a domestic constitution cannot compensate and jettison what many regard as essential to the idea of human rights: their universal validity. In the following, I shall explore both alternatives, to see whether they can be modified in order to maintain the co-originality thesis. 
First, however, let me conclude by reflecting on why the co-originality thesis produces this dilemma. Habermas anchors his thesis about the co-originality of rights and democracy in the legal medium of the modern state, not only as an account of how they have developed historically, but also, as we have seen, in order to explicate their normative interrelation. According to this view, using 'civil liberties' and 'human rights' as interchangeable terms is not to conflate the concepts: on the contrary, being citizen of a legally constituted democratic community is a necessary condition for having substantive rights. Not even in the abstract sense could rights exist before consociates under law decide to regulate their common affairs by the medium of law. And if individual rights do not exist prior to the state, then they also seem not to exist outside of the state. While Habermas as a theorist of global governance participates in the movement to decouple constitutionalism from the state and theorize the ways in which new modes of governance herald a 'post-national constellation', his normative theory of democracy relies, in crucial respects, on a statist paradigm, according to which free and equal citizens acts as the constituent power and foundational authority of the constitution (cf. Kumm 2009). Put differently, Habermas's account of the constitutionalisation of international law eventually suffers from an insufficiently internationalized account of constitutional law.

\section{International human rights in a global political order}

We finally turn to a problem that arises from the claim that human rights and democracy are co-original and interdependent once we read it not as a justification of the public and private autonomy of consociates under law, but as a cosmopolitan theory of international human rights. The problem is how to justify the idea of human rights if we insist that such rights can only be realized - normatively, conceptually, and practically - through a legal- 
democratic political order, an institutional requirement neither international institutions nor many states seem to satisfy. This puzzle has recently occupied Habermas, as well as critics, in developing a cosmopolitan model of international order. I shall, in turn, analyse Habermas's proposal, raise some considerable objections to it, and suggest an alternative strategy. My aim is not to gauge the merits of Habermas's cosmopolitan design for a multi-level global order per se (see, e.g., Anderson 2005; Fine \& Smith 2003; Flynn 2003; Hedrick 2007; Humrich 2007; Scheuerman 2008), but rather to assess the resources within this construction for maintaining the co-originality thesis. In his works on global governance, Habermas is intriguingly laconic about the democratic legitimation of human rights, and existing international human rights practices and institutions play only a peripheral part in his model, even as they represent a critical case of increasingly sovereignty-constraining international law and pose obvious legitimation challenges for the cooriginality claim. I shall argue that Habermas's model of global governance would represent a considerable devolution of the existing international rights regime and yet fails to do justice to the idea that rights require democratic articulation. In the following section, I shall suggest a way out of this morass, by confronting the discourse-theoretic approach to human rights with an empirical account of the practice of human rights.

In a series of recent works, Habermas has explored the global route, envisioning a three-tiered cosmopolitan model of global governance that would establish what he calls a global domestic politics without a world government. The model distinguishes political governance at three different levels, dominated by different types of actors: At the supranational level a reformed United Nations takes pride of place, 'specialized in securing peace and implementing human rights worldwide' (Habermas 2008b). At the transnational level functional, multilateral regimes negotiate diverse regulatory issues of 'world do- 
mestic policy', such as economic redistribution, environmental problems and collective risks, and a manageable number of 'global players' - regional entities modelled on the European Union - would both represent interests and implement policies on a continental scale. At the national level, finally, states would remain the most important source of authority and democratic legitimacy.

Within this scheme for a reformed, constitutionalized global political order, how are human rights to be articulated, legitimated and implemented? Habermas maintains that the supranational world organization's competence would be restricted to two functions: Securing peace and protecting human rights globally. The world organization would authorize states to guarantee the basic rights of their citizens within their territory, but retains the authority to take measures against individual governments that violate international rules. The world organization would thus stand in an hierarchical relation to states, but still borrow sanctioning capacities from able and willing members in order to employ force in emergencies (Habermas 2008b). The world organization's General Assembly, the delegates of which would need to balance both cosmopolitan and national concerns, would be in charge of interpreting and elaborating the fundamental principles of global politics, including standards of human rights, which would be binding on negotiations at the transnational level (Habermas 2008b). Habermas also envisions that well-off states should muster a certain cosmopolitan solidarity towards less fortunate societies, in order to ensure that all cosmopolitan citizens have a fair opportunity to practise their political and civic basic rights.

Hence, the institutional responsibility for elaborating and implementing human rights norms rests with the supranational level, which raises the issue of how its authority in this domain would be legitimated. Habermas rejects global, cosmopolitan democracy 
and a world government because, he claims, the necessary bonds of solidarity would not be strong enough at the global level to underpin a cosmopolitan democracy (cf. Habermas 2011). While he sees no structural reason why national civic solidarity and welfare state policies could not extend beyond the nation-state, the global arena would simply lack an ethical-political identity and cosmopolitan solidarity that could bear the weight of a global democracy. Moreover, against cosmopolitan democrats' call for an all-inclusive global democratic community, Habermas (2001b, p.107) argues that democratic selfdetermination requires an enclosed, demarcated group, rather than an unbounded community.

However, Habermas sees a potential for international law to gradually evolve into a binding legal order that puts passive constraints on global governance. His solution is to decouple the concepts of the state, as a hierarchical bureaucratic apparatus monopolizing the legitimate means of violence, and the constitution, defining a horizontal association of free and equal citizens (Habermas 2004, p.135; cf. Habermas 2008b). Thus, he argues, the supranational level could still be constitutionalized without relying on a global state or a world federation for enforcement, nor on a particular demos and a constitutional founding moment. While this nascent global constitution is supposedly detached from democracy and governmental authority, it must remain connected to the 'communicative flows' of legitimacy from democratic, constitutional states and national parliaments (Habermas 2004, p.139; Habermas 2008a, p.322).

I will present four main objections to Habermas's model for a reformed global order, and the role that human rights and democracy play within it, concerning (1) the political function of human rights, (2) their democratic legitimation, (3) the continued existence of illiberal regimes and (4) the dynamic of institutional transformation. First, Ha- 
bermas seems to downplay the political nature of decisions about human rights and peace, assuming that supranational policymaking would be matters of legal enforcement, while genuinely political matters (such as issues involving redistribution) would be delegated to the transnational level. This assurance rings hollow, argues Todd Hedrick (2007, p.407), 'as if there are no political controversies surrounding the substantive content, application and enforcement of human rights.'

Perhaps Habermas seeks to downplay the political nature of decisions about human rights because he has only weak, indirect legitimation mechanisms to offer at the supranational level. For instance, he indicates that if the Security Council 'would deal with $[\ldots]$ issues of securing peace and protecting human rights in accordance with fair procedures, hence in an impartial and non-selective manner' (Habermas 2008a, p.343), it could count on support from an existing worldwide background consensus, insofar as its actions are based on a limited interpretation of human rights. Habermas here seems to concur with minimalist political conceptions of human rights, which see the main function of human rights as agreed upon inter-governmental norms of legitimacy, the large-scale violation of which may serve as reasons for international intervention (Anderson 2005; Baynes 2009a). I see two problems with this view. Firstly, a substantively minimalist account of human rights may be as politically contentious as more ambitious interpretations, since even the most uncontroversial human rights norms do not specify themselves: they open for disagreements about their content, their relative priority where they conflict, and when they can permissibly be abrogated to avoid greater harm (Buchanan 2008), etc. Moreover, the current practice of the United Nations demonstrates that when the enforcement of basic human rights is devolved to multilateral institutions dependent on the good will and military prowess of great powers, politicization and selective bias usually flourish - as 
Habermas is well aware. And while a philosopher at the drawing desk may perhaps neatly sort policy issues into distinct functional domains, in political practice the very definition of policy problems are often a matter of political conflict in its own right (as, for instance, people reasonably disagree over whether climate change adaptation is a matter of protecting human rights or of redistributing economic burdens).

Secondly, compared to the existing contemporary practice, Habermas's view neglects a host of political roles that international human rights serve. Not only do they supplement and bolster rights provisions in domestic constitutions; they also provide standards for supervision and criticism of governments by citizens, NGOs, treaty bodies or other states; for when government officials should be prosecuted domestically or internationally for human rights violations; for considering complaints and adjudicating cases before international human rights courts; and for foreign aid, political reform and good government (cf. Nickel 2006, p.270). In particular, Habermas assigns no prominent function to the judicial institutions of the international human rights regime, apart from expressing moderate enthusiasm for the UN's supervisory organs and the International Criminal Court (cf. Habermas 2004, p.161; Habermas 2010). To judge by his remarks on the World Trade Organization's dispute settlement mechanism (Habermas 2008a, p.349), he is sceptical towards international judicial organs which lack the direct legitimation provided by a corresponding democratic legislature that can lay down the law and correct judicial decisions - a scepticism which, presumably, would apply to the existing international human rights judiciary, too, since it entails similar legitimacy challenges, for example when a court dynamically interprets its founding international treaty beyond original intent. Yet, to the extent that indirect legitimation of international human rights governance presupposes impartial and fair procedures to authoritatively specify human rights 
norms, semi-independent regional and international human rights treaty bodies seem more likely candidates than the political bodies of the UN. To conclude: By limiting the political function of human rights and by placing the authority over human rights with the Security Council rather than within the existing, multifaceted international human rights regime, Habermas's institutional proposals implies a downgrade compared to current practice.

The second problem is that in his model of global governance, Habermas downplays the role of democratic legitimation, which is crucial for the co-originality claim. Habermas suggests that the legitimation of authority at both the supranational and transnational levels must rely on the 'flows of legitimacy' from democratic, constitutional nationstates. Additionally, if reformed global institutions conform to established constitutional principles and processes, an informal global public opinion could suffice to meet the 'remaining need for legitimation' (Habermas 2008b). Now, he might be right that there is little prospect for truly democratic procedures at the supranational level, so that we must settle with a more limited yet reformed version of the current international order, where whatever democratic legitimacy there is must be transmitted from national parliaments of constitutional democracies. But such a thin, delegation-based account of legitimation must remain highly problematic for Habermas's claim that rule of law and democracy are internally related, which applies to all settings where the rule of law is institutionalized (Hedrick 2007).

Moreover, placing the authority to give substance and shape to international human rights, and the broader legal framework, with an at best indirectly legitimated supranational level which stands in an hierarchical relation to states, seems to imply that human rights are imposed on democracy (or on any political community) from the outside, be- 
yond the control of consociates under law. While relying on democracy at the national level to provide superordinate levels of the world order with legitimacy might seem both more feasible and more desirable, such a fall-back position comes with another trade-off: It weakens the cosmopolitan ambition in the co-originality claim and the universal moral validity of human rights. If human rights can only be given substance by an actual historical legislator, and if that authority is distributed to every national constitutional project, then rights would likely become rather differently articulated and implemented in different democratic states. The result would not be a system of universal human rights interdependent with democracy, but (at best) a series of parallel systems of rights, legitimated and substantiated within each constitutional project and thus possibly quite differently institutionalized in each state (Fine \& Smith 2003, p.471f). That is more or less what Habermas concedes when he insists that substantive rights must be formulated by a particular legislator. Yet this solution fails to illuminate how human rights would be justified and specified in settings where democratic procedures are absent or seriously flawed, and one might suspect that those are the situations where such justifications are most needed.

Relatedly, the third problem concerns whether the co-originality thesis can account for the troubling fact that far from all states today are democracies. In principle, Habermas requires a great deal of conformity from the states in the international system (Moon 2003). Unlike Rawls, for example, Habermas disallows toleration of non-liberal but decent peoples: All states would need to become rights-based, constitutional democracies (cf. Tinnevelt \& Mertens 2009). This problem is not just conceptual, however, but political too, as it concerns, for instance, what role - if any - there is in international society for regimes that fall short of Habermas's high standards of constitutional democracy and human rights. To side-line the matter, as Habermas (2008b) does, seems a mistaken ap- 
proach for theorizing about international politics, since a variety of regimes continue to exist and pose a difficult test to any cosmopolitan theory of international order. In practice, Habermas seems willing to accept authoritarian, rights-violating regimes as members of international society as the contradictory price to be paid for the ongoing constitutionalization of international order (Habermas 2004, p.163f). However, even if the policies of the world organization were legitimated through flows of legitimacy from democracies, they could hardly be considered legitimately binding on the populations of nondemocracies, which generate no internal legitimacy to delegate upwards (cf. Caney 2009).

Finally, what would convince or coax states and other agents involved to act so as to realize his model? Habermas identifies few of the factors that would push global order towards his desired model, apart from pointing to the need for governments and people to learn, by 'overcoming an obstinate frame of mind' and internalizing cosmopolitan norms (Habermas 2008b). This omission is problematic in two respects: Firstly, the model's theoretical credibility is undermined if it fails to specify the dynamic by which the world could move from the current state of affairs to his preferred political order. Habermas paints a surprisingly realist image of international politics as dominated by power-based negotiations among self-interested global players (Humrich 2007). From such an inhospitable ground, the prospects for constitutionalizing international law certainly seem glum. Yet he fails to acknowledge how persistent political differences set the terms for United Nations reform. While the past seven decades have seen many calls for major institutional overhaul, the world organization has always reformed incrementally, slowly and reluctantly, because its founders deliberately made charter amendment difficult and because great and small powers alike prefer an institutional status quo (Luck 2005). Perhaps un- 
wittingly (Habermas 2007), Habermas is considerably more sceptical than international relations scholars who have appropriated his theory of communicative action for world politics to the possibility that discursive modes of interaction help transform states' interests and identities (Risse 2000). Arguably, the constitutionalization of international law has already moved beyond not only Habermas's realist picture of world politics, but also his model of global governance, which is too undemanding in terms of normative legitimation (Humrich 2007, p.395). Indeed, the international human rights system has, in important respects, become a constitutionalized regime of international law, especially in Europe, although its role in constitutionalizing international law more widely should not be exaggerated (Gardbaum 2009, pp.245f, 251). Secondly, omitting a dynamic of change also undermines the model's practical feasibility and relevance as a normative ideal for a global political order: It fails to guide political action. For a normative theory of this kind, that should count as a serious defect.

\section{Human rights struggles as democratic iterations}

Elaborating his model of global governance, Habermas may seem to have painted himself into a corner, where he compromises the co-originality thesis as a theory of international human rights. His stiff, top-down institutional blueprint fails to redeem its cosmopolitan promise (Bohman 2011) and its discourse-theoretic potential (Humrich 2007). So how could a Habermasian get out of this morass?

In this final section, I shall attempt a solution. My argument draws on two resources: Seyla Benhabib's $(2004 ; 2006 ; 2011)$ recent work on a discourse theory of human rights which I confront with empirical International Relations approaches to the practice of international human rights. Combining, thus, social scientific scholarship with 
normative political philosophy helps us chart the limits and possibilities of change in world politics, indicating alternatives to utopianism and scepticism (Price 2008).

Overall, Benhabib's version of co-originality is consistent with Habermas's and so, I shall argue, she encounters similar problems. In particular, insisting that democratic self-determination is a presupposition for legitimating human rights leads to the uncomfortable conclusion that human rights would only be effective and valid where they are least needed, which is not only normatively dissatisfying but fits poorly with historical experience. Instead, I suggest shifting the emphasis from ideal institutions to actual practices by which individuals and groups use international legal norms to ensure their rights vis-à-vis governments. Modifying correspondingly Benhabib's concepts of jurisgenerativity and democratic iterations indicates how a discourse-theoretic account of human rights could avoid at least some of the problems in Habermas's cosmopolitan model.

Building on Hannah Arendt's notion of a 'right to have rights', Benhabib suggests a three-step discourse-theoretic account which anchors rights in a basic norm, immanent in discursive processes, to give reasons (cf. Baynes 2009a). That norm, in turn, implies one fundamental right of every human being to have rights, that is, a moral right to have the legal rights of a member of a community. Finally, the moral principle of right needs to be specified, through democratic procedures, into a more extensive scheme of legal rights. In short: 'Human rights are moral principles that protect the exercise of your communicative freedom and that require embodiment in legal form' (Benhabib 2011, p.68). Thus, Benhabib too emphasizes the intrinsic connection between human rights and selfdetermination:

'The principle of rights binds the will of the democratic sovereign because the equality of all under the law must be recognized for self-government to be a 
meaningful practice at all. Once this democratic equality of law-giving citizens is presupposed, then the schedule of rights in each polity can be determined by the discursive articulation of legislative processes.' (Benhabib 2011, p.74f)

This corresponds, more or less, to Habermas's account of co-originality and encounters similar problems. Benhabib emphasises the ideal institutional presuppositions for rights and democracy to be co-constitutive, and insists that cosmopolitan norms, as a matter of fact, must be applied, legitimated and implemented through legislation within a political community - the process through which citizens come to regard themselves as both authors and addressees of law (Benhabib et al. 2006, p.48f). A state offers both the governmental apparatus necessary to enforce (or violate) human rights and the representative public institutions required for their on-going legitimation (Benhabib et al. 2006, p.169). She grants that polities may legitimately vary in the way they legally and constitutionally interpret and contextualize the scheme of rights, but only insofar as such variations result from the practice of public autonomy (Benhabib 2011, p.74f). Hence, this emphasis on democratic self-determination as a normative and factual presupposition for legitimating the schedule of rights leads back to the problem of universality: To the extent that the legitimation and implementation of human rights require 'the sites provided by liberal democracies to flourish' (Benhabib et al. 2006, p.169), human rights norms will only be normatively justified and empirically productive where they are least necessary. Moreover, insisting on this link to pre-existing democratic institutions may both give alleged democracies too much latitude to interpret and implement human rights and underestimate how people can actually appropriate international human rights norms even in the absence of institutions of self-government. Finally, at times Benhabib (e.g., 2004, p.29f), 
like Habermas, seems to suggest that the international human rights regime's chief function is to define inter-state norms for the prevention of mass atrocities.

Against this view, I shall suggest that rethinking international human rights practice in terms of political struggles for equal standing, chiefly exercised at the domestic level, can both make sense of the co-originality thesis in an international order and allow it to challenge dominant political conceptions of human rights. Historically, struggles for human rights have been essential for establishing the conditions under which citizens can enjoy both individual autonomy and collective self-government, a theme that has recently been explored in different strands of International Relations scholarship. In Christian Reus-Smit's historical-sociological work (2013; 2011b), mobilization for individual rights have played a crucial role through five successive waves of expansion of the international system, from the Westphalian settlement to the demise of the Soviet Union. In each such wave, imperial subjects have mobilized notions of individual rights to challenge the legitimacy of hierarchical systems of imperial rule and the institutionalized unequal entitlements that support them. Eventually, as imperial centres have failed to resolve such crises of legitimacy, subject peoples have opted for establishing independent sovereign states as the best way to safeguard the rights of citizens as free and equal. The fourth of these waves - decolonization after the second world war - dissolved the remaining European empires, but also delegitimized the institution of empire as such, a process in which the emergent international human rights regime played an important part: Early independent states worked within the United Nations to establish the International Bill of Rights, and grafted a norm of self-determination onto these new international instruments. In the fifth wave, domestic opposition groups mobilized the human rights norms 
recognized in the Helsinki Final Act (1975) to challenge Communist rule, thereby contributing to the dissolution of the Soviet empire (Thomas 2001).

Another line of International Relations research has sought to assess the impact of this expanding international human rights regime. Its political significance is frequently misunderstood because it differs in crucial respects from other international regimes: It does not regulate inter-state externalities or represent mutual gains for contracting parties, and there is no reciprocal enforcement, as mobilizing inter-state action for the protection of individual rights is too costly, risky and hard to legitimize (Moravcsik 2000; Donnelly 2002, p.178f; Simmons 2009, p.121ff; Schaffer 2013). Yet internationally negotiated human rights treaties often have significant political influence; it just occurs in a different domain than where students of international law and politics are prone to look: the domestic realm. Conditioned by domestic legal-political institutions, international human rights norms may influence government policy chiefly by providing relatively weak domestic agents with powerful tools. Specifically, for human rights norms to generate such domestic effects, their legal form is crucial (Donnelly 2006). In many states, ratification of international treaties, unlike other forms of inter-state agreements, involves significant domestic ex ante costs. Treaties can affect domestic elite agendas, even where governments support their purpose; open for strategic litigation by individuals and their supporters utilizing international human rights law in domestic courts; and spark broader mobilization to claim the rights treaties contain (Simmons 2009, chap.4). International human rights law provides activists "with political opportunities, material and human resources, vocabularies for framing and sources of new identity and movement actorhood" (Tsutsui et al. 2012, p.386). Notably, the influence is greatest neither on stable democracies nor on authoritarian regimes, but on transitioning states, where a government's self-binding to 
international treaties may help consolidating democracy and the rule of law (Moravcsik 2000; Hafner-Burton 2012, p.268f), and where rights-claiming groups have both "the motive and the means to demand the protection of their rights as reflected in ratified treaties" (Simmons 2009, p.17).

The approaches emphasizing stakeholder mobilization differ from another line of IR scholarship on international human rights norms. Partly influenced by Habermasian communicative action theory, a prominent constructivist approach models the influence of international human rights norms as a spiral process (Risse et al. 1999; Risse et al. 2013), by which transnational networks of activists, mobilizing liberal states and international organizations, pressure rights-violating governments to comply with human rights standards - from denial via tactical concessions to genuine persuasion. However, focusing on outside advocacy, these models underestimate "the significance of the domestic realm as the main battleground for social change" (Schmitz 2004, p.409) and underplay the agency of those who have the strongest interest in whether a government complies with its human rights commitments, namely stakeholders in that country (Simmons 2009, p.356).

How could these images of the practice of human rights inform the discoursetheoretic conception of co-originality? While Benhabib remains equally attached to the ideal institutional requirements for co-originality to hold, she also advances on Habermas by developing a notion of jurisgenerative politics through democratic iterations, which, although its contours remain vague, could explain how actual rights discourses, powered by universal human rights norms, can transform current institutional practices. Jurisgenerativity refers to the legal discourse's capacity to expand its own horizon. As an instance of such a politics, international human rights norms can enable previously exclude per- 
sons to enter the public sphere and claim rights. Benhabib calls these processes democratic iteration, through which a wide range of agents in strong and weak public spheres appropriate, contest, and enact universal, cosmopolitan norms in particular polities. Iteration is not just repetition: subjects re-signify and transform the meaning of norms as they employ them (Benhabib 2011, p.15), a process well-documented in empirical studies of the local vernacularization of global human rights norms (Tsutsui et al. 2012, p.381). One might read 'democratic iterations' as an elaboration of Habermas's notion of the constitutional project as a self-correcting learning process, yet it does not presuppose a preconstituted demos of free and equals giving law to itself. Recently, Habermas has similarly emphasized how the norms of human rights are expanded through struggles, as those who have experienced humiliation, degradation and oppression express their grievances in the vocabulary of human rights (Habermas 2010, p.466; cf. Flynn 2011; Forst 2010). As a moral point of reference in such struggles, human dignity, which Habermas (2010, p.469) sees as a reflection of the co-originality claim, also serves an inventive function, revealing where new rights ought to be formulated or existing rights need to be expanded to previously excluded groups or to new situations, and eventually codified in law.

From the point of view of Habermas's international theory, this practice-centred approach to co-originality has several attractive features. First, in contrast to Habermas's top-heavy model for cosmopolitan reform, shifting the theoretical focus to the discursive processes and practices of rights politics both serves to specify how it could be acted upon and provides a logic of systemic change: The key agents of international human rights reform are not only the disinclined global players or the inert international institutions they have created, but also the persons and groups, within and across polities, who collectively appropriate human rights norms to achieve equal status. Where they are successful, 
states change their behaviour to comply more consistently with international human rights. The power of such stakeholder agency should not be exaggerated - setbacks are common and progress often only incremental - but neither should it be disregarded by any theory that purports to make sense of the politics of human rights.

Second, specifically, such democratic iterations indicate how the sites and subjects of democratic politics are brought about in the first place. In Habermas's account of cooriginality as a quasi-historical account of the evolution of modern constitutional democracy, the regulatory state still seems more primordial than both rights and democracy. However, this account underplays how individual rights are not just the product of a system of positive law and its democratic legitimation, but have also causally contributed to globalising the system of self-governing states and expanding the moral universe of rights-holders and the range of rights they can claim. In that sense, rights and democracy are 'co-original' long before the institutions of liberal democratic states allow them to flourish. Benhabib (2011, p.135) admits as much by suggesting that once we refocus on how civil society actors mobilize across national boundaries to appropriate international human rights norms, the sharp normative distinction between liberal democracies and other types of regimes starts to lose its relevance. David Ingram (2008) suggests that once we understand the politics of human rights as the activity by which previously excluded persons and groups come to claim their rights, the target for such criticism could in principle be any body exercising public authority, not only within the framework of a constitutional state. However, the state remains the primary addressee of such claims, since basic rights require an institution authorized and empowered to protect them (Reus-Smit 2009, p.26; Forst 2010). 
Third, re-focusing on the discursive practices in rights struggles helps the discoursetheoretic conception of human rights meet the charge of juridification. Critics claim that insisting that moral rights must be embodied in positive law entails that the domain of law encroaches upon that of politics, turning reflective citizens into energetic, selfinterested litigants seeking retribution or compensation in courts, rather than aspiring for broader social change (Ingram 2009). But legalization is crucial for international human rights law to serve its jurisgenerative functions, because it provides explicit normative standards that human rights advocates can employ against governments (Donnelly 2006) and the fact that human rights are useful in this manner also explains their aspirational value: They are legal tools for effecting social change and the equal standing of persons. Thus, rather than precluding politics, legalized international human rights provide opportunities for political mobilization and democratic contestation.

Fourth, while reinterpreting the co-originality claim in terms of struggles for human rights offers an alternative to Habermas's rigid scheme for global reform, this move also allows the discourse-ethics approach to challenge existing political conceptions in the philosophy of human rights. In contradistinction to moral conceptions, which see human rights as pre-institutional entitlements persons have simply by virtue of being human, political conceptions approach human rights by reconstructing their role or function in contemporary international affairs (for overviews, see Baynes 2009b; Buchanan 2010). The most prominent political conceptions model human rights as an international agreement among (liberal) states that specifies standards of legitimacy: When should other states tolerate a government, even if it pursues certain illiberal practices and, conversely, when may they take action, including sanctions or intervention, against a government that systematically violates or fails to protect human rights? As I have argued, Habermas con- 
curs with this view of the function of human rights when he places human rights as the key task of the UN leadership, as does Benhabib when she describes the existing human rights regime chiefly in terms of instruments of international criminal, humanitarian and refugee law. Yet in construing human rights as inter-state agreements ideally enforced top-down by liberal great powers against recalcitrant regimes and rights violators, the leading political conceptions fundamentally oversee what may be the most significant function of the practice of human rights in global affairs: It authorizes and empowers individuals to vindicate their rights against political authority (Donnelly 2002, p.12; cf. Reus-Smit 2011a). If we recast the discourse-theoretic approach in terms of struggles through which stakeholders collectively mobilize universalist norms about individual rights against oppressive authorities in order to realize their equal status, it offers a dynamic counter-narrative to the dominant political conceptions, which arguably better captures the real, innovatory social function of the practice of human rights.

Finally, noticing how Habermas is at pains to extend his theory to an international order, critics have argued that he should rather embrace some form of world government to provide enforcement capacities to global governance (Scheuerman 2008; Tinnevelt \& Mertens 2009). Habermas partakes in a broader project, inspired by globalization theory and cosmopolitanism, that seeks to move international and political theory beyond an allegedly already outmoded Westphalian model of state sovereignty as absolute, territorial authority (e.g. Held 2002). On this project, the emergence of an international human rights regime represents the ultimate evidence that cosmopolitan norms are eroding national sovereignty as the key organizing principle of international order (Goodhart 2005, p.132). However, in order to demonstrate that a cosmopolitan transition is under way, this post-sovereigntist narrative rests on a mythical account of the sovereignty regime suppos- 
edly being displaced (Rosenberg 2000, p.10). In particular, that account neglects how sovereignty, as a dynamic principle by which law and politics are mutually constituted, has continually been reconfigured through legitimating discourses of popular sovereignty and individual rights (Cohen 2004; Dahbour 2006; Reus-Smit 2001). From this perspective, the postnational attempt to decouple democratic constitutionalism from the state certainly seems disconcerting (Scheuerman 2009). However, the approach I have indicated here, which combines the co-originality claim with the causal and normative dynamic of rights mobilization targeting the institutional framework of a state, may provide a plausible approximation for how the co-constitution of law and politics reconfigures, rather than erodes, sovereignty.

\section{Conclusion}

This paper has analyzed Jürgen Habermas's claim that democracy and human rights are co-original, as it has developed from democratic to international theory and in response to various objections. My argument has mainly focused on confronting the Habermasian normative theory with an account of the practice of international human rights, and especially two salient features: Domestic constitutional rights are interlaced with international human rights law, yet international human rights norms are mainly enforced (if at all) domestically rather than internationally. Reconceiving the practice of international human rights in this fashion has two important consequences for the co-originality thesis, I have argued. First, in his account of democratic constitutionalism, Habermas relies on the conception of the constitutional project as a particular community of free and equal citizens recursively giving law to itself. However, while this conception might help meet the regress objections, it makes it more difficult for co-originality to make sense of the increas- 
ing enmeshment between constitutional and international human rights. Second, in the absence of a global democratic regime, Habermas has difficulties justifying international human rights. Instead, he comes to sketch a top-down model of global governance where human rights, as a binding framework of international law, has only weak, indirect grounding in the democratic legitimation procedures he argues are necessary if citizens are to regard themselves as both authors and addressees of law.

Here, I have indicated a different approach that emphasises the struggles through which societal groups bring international human rights law to bear on state institutions, rather than projecting domestic norms of constitutional democracy to global governance. For the co-originality thesis and the discourse theory conception of human rights, I believe a fruitful road ahead lies in shifting the focus from ideal institutions to actual practices. Within the approach, there are conceptual resources for making sense of how stakeholders mobilize to employ international human rights norms, modifying the meaning of universalist ideas as they apply them to challenge power in their particular circumstances. Focusing on human rights struggles also helps asserting a normative concern that has always been at the heart of Habermas's discourse theory: That only actual public deliberation and contestation, involving the real persons affected, can produce legitimately binding collective norms. 


\section{References}

Anderson, P., 2005. Arms and rights: Rawls, Habermas and Bobbio in an age of war. New Left Review, 31(1), pp.5-40.

Baynes, K., 1995. Democracy and the Rechtsstaat: Habermas's Faktizität und Geltung. In The Cambridge companion to Habermas. Cambridge: Cambridge University Press, pp. 201-232.

Baynes, K., 2009a. Discourse ethics and the political conception of human rights. Ethics \& Global Politics, 2(1).

Baynes, K., 2009b. Toward a Political Conception of Human Rights. Philosophy \& Social Criticism, 35(4), pp.371-390.

Benhabib, S. et al., 2006. Another cosmopolitanism, Oxford: Oxford University Press.

Benhabib, S., 2011. Dignity in adversity: Human rights in troubled times, Cambridge: Polity Press.

Benhabib, S., 2004. The rights of others: Aliens, residents and citizens, Cambridge: Cambridge University Press.

Bogdandy, A. von \& Venzke, I., 2012. In Whose Name? An Investigation of International Courts' Public Authority and Its Democratic Justification. European Journal of International Law, 23(1), pp.7-41.

Bohman, J., 2011. Beyond overlapping consensus: Rawls and Habermas on the limits of cosmopolitanism. In J. G. Finlayson \& F. Freyenhagen, eds. Habermas and Rawls: Disputing the political. Routledge Studies in Contemporary Philosophy. London: Routledge, pp. 265-280.

Buchanan, A., 2008. Human rights and the legitimacy of the international order. Legal Theory, 14(01).

Buchanan, A., 2010. The Egalitarianism of Human Rights. Ethics, 120(4), pp.679-710.

Caney, S., 2009. The responsibilities and legitimacy of economic international institutions. In L. H. Meyer, ed. Legitimacy, justice and public international law. Cambridge: Cambridge University Press.

Cohen, J., 1999. Reflections on Habermas and democracy. Ratio Juris, 12(4), pp.385416.

Cohen, J.L., 2004. Whose sovereignty? Empire versus international law. Ethics \& International Affairs, 18(3), pp.1-24.

Cronin, C., 2006. On the possibility of a democratic constitutional founding: Habermas and Michelman in dialogue. Ratio Juris, 19(3), pp.343-369. 
Dahbour, O., 2006. Advocating sovereignty in an age of globalization. Journal of Social Philosophy, 37(1), pp.108-126.

Donnelly, J., 2006. The virtues of legalization. In S. Meckled-Garcia \& B. Çal1, eds. The legalization of human rights: Multidisciplinary perspectives on human rights and human rights law. London: Routledge, pp. 67-80.

Donnelly, J., 2002. Universal human rights in theory and practice, Ithaca: Cornell University Press.

Elkins, Z., Ginsburg, T. \& Simmons, B.A., 2013. Getting to Rights: Treaty Ratification, Constitutional Convergence, and Human Rights Practice. Harvard International Law Journal, 54(1), pp.61-95.

Fine, R. \& Smith, W., 2003. Jürgen Habermas's theory of cosmopolitanism. Constellations, 10(4), pp.469-487.

Finlayson, J.G. \& Freyenhagen, F. eds., 2011. Habermas and Rawls: Disputing the political, New York: Rouledge.

Flynn, J., 2003. Habermas on human rights: Law, morality, and intercultural dialogue. Social Theory and Practice, 29(3), pp.431-457.

Flynn, J., 2011. Two models of human rights: Extending the Rawls-Habermas debate. In J. G. Finlayson \& F. Freyenhagen, eds. Habermas and Rawls: Disputing the political. Routledge Studies in Contemporary Philosophy. London: Routledge, pp. 247-264.

Føllesdal, A., Schaffer, J.K. \& Ulfstein, G. eds., 2013. The legitimacy of international human rights regimes: Legal, philosophical and political perspectives, Cambridge: Cambridge University Press.

Forst, R., 2010. The Justification of Human Rights and the Basic Right to Justification: A Reflexive Approach. Ethics, 120(4), pp.711-740.

Gardbaum, S., 2009. Human rights and international constitutionalism. In J. L. Dunoff \& J. P. Trachtman, eds. Ruling the world? Constitutionalism, international law and global governance. Cambridge: Cambridge University Press, pp. 233-257.

Gilabert, P., 2005. The substantive dimension of deliberative practical rationality. Philosophy \& Social Criticism, 31(2), pp.185-210.

Goodhart, M., 2005. Democracy as human rights: Freedom and equality in the age of globalization, Routledge: New York.

Habermas, J., 1996. Between facts and norms: Contributions to a discourse theory of law and democracy, Cambridge, MA: MIT Press.

Habermas, J., 2008a. Between naturalism and religion: Philosophical essays, Cambridge: Polity Press. 
Habermas, J., 2001a. Constitutional democracy - A paradoxical union of contradictory principles? Political Theory, 29(6), pp.766-781.

Habermas, J., 2004. Der gespaltene Westen: Kleine politische Schriften, Frankfurt am Main: Suhrkamp.

Habermas, J., 2007. Kommunikative Rationalität und grenzüberschreitende Politik: eine Replik. In P. Niesen \& B. Herborth, eds. Anarchie der kommunikativen Freiheit: Jürgen Habermas und die Theorie der internationalen Politik. Frankfurt am Main: Suhrkamp, pp. 406-459.

Habermas, J., 1998a. Remarks on legitimation through human rights. Philosophy \& Social Criticism, 24(2-3), pp.157-171.

Habermas, J., 2011. Reply to my critics. In J. G. Finlayson \& F. Freyenhagen, eds. Habermas and Rawls: Disputing the political. Routledge Studies in Contemporary Philosophy. London: Routledge, pp. 283-304.

Habermas, J., 2010. The concept of human dignity and the realistic utopia of human rights. Metaphilosophy, 41(4), pp.464-480.

Habermas, J., 2008b. The Constitutionalization of International Law and the Legitimation Problems of a Constitution for World Society. Constellations, 15(4), pp.444-455.

Habermas, J., 1998b. The inclusion of the other: Studies in political theory, Cambridge, MA: The MIT Press.

Habermas, J., 2001b. The postnational constellation: Political essays, Cambridge: Polity.

Hafner-Burton, E.M., 2012. International Regimes for Human Rights. Annual Review of Political Science, 15(1), pp.265-286.

Hedrick, T., 2007. Constitutionalization and democratization: Habermas on postnational governance. Social Theory and Practice, 33(3), pp.387-410.

Hedrick, T., 2010. Rawls and Habermas: Reason, pluralism, and the claims of political philosophy, Stanford, Calif: Stanford University Press.

Held, D., 2002. Law of peoples, law of states. Legal theory, 8(2).

Humrich, C., 2007. Faktizität ohne Geltung? Oder: Hat die Konstitutionalisierung des Völkerrechts eine diskurstheoretische Chance? In P. Niesen \& B. Herborth, eds. Anarchie der kommunikativen Freiheit: Jürgen Habermas und die Theorie der internationalen Politik. Frankfurt am Main: Suhrkamp, pp. 383-405.

Ingram, D., 2009. Of sweatshops and subsistence: Habermas on human rights. Ethics \& Global Politics, 2(3), pp.193-217.

Ingram, J.D., 2008. What Is a "Right to Have Rights"? Three Images of the Politics of Human Rights. American Political Science Review, 102(04), p.401. 
Kassner, J., 2006. Is everything really up for grabs? The relationship between democratic values and a democratic process. The Journal of Political Philosophy, 14(4), pp.482-494.

Kumm, M., 2009. The cosmopolitan turn in constitutionalism: On the relationship betwen constitutionalism in and beyond the state. In J. L. Dunoff \& J. P. Trachtman, eds. Ruling the world? Constitutionalism, international law and global governance. Cambridge: Cambridge University Press, pp. 258-324.

Larmore, C., 1999. The moral basis of political liberalism. The Journal of Philosophy, XCVI(12), pp.599-625.

Luck, E.C., 2005. How Not to Reform the United Nations. Global Governance, 11(4), pp.407-414.

Mahoney, J., 2001. Rights without dignity? Some critical reflections on Habermas's procedural model of law and democracy. Philosophy \& Social Criticism, 27(3), pp. $21-40$.

McCarthy, T., 1999. On reconciling cosmopolitan unity and national diversity. Public Culture, 11(1), pp.175-208.

Michelman, F., 1997. How can the people ever make the laws? A critique of deliberative democracy. In J. Bohman \& W. Rehg, eds. Deliberative democracy: Essays on reason and politics. Cambridge, MA: MIT Press.

Moon, J.D., 2003. Rawls and Habermas on Public Reason: Human Rights and Global Justice. Annual Review of Political Science, 6, pp.257-274.

Moravcsik, A., 2000. The origins of human rights regimes: Democratic delegation in postwar Europe. International Organization, 54(2), pp.217-252.

Nickel, J.W., 2006. Are human rights mainly implemented by intervention? In R. Martin \& D. A. Reidy, eds. Rawls's law of peoples: A realistic utopia?. Oxford: Blackwell, pp. 263-277.

Pedersen, J., 2012. Justification and Application The Revival of the Rawls-Habermas Debate. Philosophy of the Social Sciences, 42(3), pp.399-432.

Price, R., 2008. Moral Limit and Possibility in World Politics. International Organization, 62(02).

Rawls, J., 1996. Political liberalism, New York, NY: Columbia University Press.

Reus-Smit, C., 2001. Human rights and the social construction of sovereignty. Review of International Studies, 27(04).

Reus-Smit, C., 2011a. Human rights in a global ecumene. International Affairs, 87(5), pp.1205-1218. 
Reus-Smit, C., 2013. Individual Rights and the Making of the International System, Cambridge: Cambridge University Press.

Reus-Smit, C., 2009. On rights and institutions. In C. R. Beitz \& R. E. Goodin, eds. Global Basic Rights. Oxford University Press, pp. 25-48.

Reus-Smit, C., 2011b. Struggles for Individual Rights and the Expansion of the International System. International Organization, 65(02), pp.207-242.

Risse, T., 2000. "Let's Argue!": Communicative Action in World Politics. International Organization, 54(01), pp.1-39.

Risse, T., Ropp, S.C. \& Sikkink, K. eds., 2013. The persistent power of human rights: from commitment to compliance, Cambridge: Cambridge University Press.

Risse, T., Ropp, S.C. \& Sikkink, K. eds., 1999. The power of human rights: International norms and domestic change, Cambridge: Cambridge University Press.

Rosenberg, J., 2000. The follies of globalisation theory, London: Verso.

Rummens, S., 2006. The co-originality of private and public autonomy in deliberative democracy. The Journal of Political Philosophy, 14(4), pp.469-481.

Schaffer, J.K., 2013. Legitimacy, global governance and human rights institutions: Inverting the puzzle. In A. Føllesdal, J. K. Schaffer, \& G. Ulfstein, eds. The legitimacy of international human rights regimes: Legal, political and philosophical perspectives. Cambridge: Cambridge University Press, pp. 212-242.

Scheuerman, W.E., 2008. Global governance without global government? Habermas on postnational democracy. Political Theory, 36(1), pp.133-151.

Scheuerman, W.E., 2009. Postnational democracies without postnational states? Some skeptical reflections. Ethics \& Global Politics, 2(1).

Schmitz, H.P., 2004. Domestic and Transnational Perspectives on Democratization. International Studies Review, 6(3), pp.403-426.

Simmons, B., 2009. Mobilizing for human rights: international law in domestic politics, Cambridge: Cambridge University Press.

Stone-Sweet, A., 2012. A Cosmopolitan Legal Order: Constitutional Pluralism and Rights Adjudication in Europe. Global Constitutionalism, 1(1), pp.53-90.

Taylor, R., 2000. Liberalism and democracy in Habermas, Rawls, and Constant. Humane Studies Review, 13(1).

Thomas, D.C., 2001. The Helsinki effect: international norms, human rights, and the demise of communism, Princeton, N.J: Princeton University Press. 
Tinnevelt, R. \& Mertens, T., 2009. The world state: A forbidding nightmare of tyranny? Habermas on the institutional implications of moral cosmopolitanism. German Law Journal, 10(1), pp.63-80.

Tsutsui, K., Whitlinger, C. \& Lim, A., 2012. International Human Rights Law and Social Movements: States' Resistance and Civil Society's Insistence. Annual Review of Law and Social Science, 8, pp.367-396. 